\title{
Lignin triggers irreversible cellulase loss during pretreated lignocellulosic biomass saccharification
}

\author{
Dahai Gao ${ }^{1,2,3}$, Carolyn Haarmeyer', Venkatesh Balan ${ }^{1,2,3}$, Timothy A Whitehead ${ }^{1,4}$, Bruce E Dale ${ }^{1,2,3}$ \\ and Shishir PS Chundawat ${ }^{1,2,3,5^{*}}$
}

\begin{abstract}
Background: Non-productive binding of enzymes to lignin is thought to impede the saccharification efficiency of pretreated lignocellulosic biomass to fermentable sugars. Due to a lack of suitable analytical techniques that track binding of individual enzymes within complex protein mixtures and the difficulty in distinguishing the contribution of productive (binding to specific glycans) versus non-productive (binding to lignin) binding of cellulases to lignocellulose, there is currently a poor understanding of individual enzyme adsorption to lignin during the time course of pretreated biomass saccharification.
\end{abstract}

Results: In this study, we have utilized an FPLC (fast protein liquid chromatography)-based methodology to quantify free Trichoderma reesei cellulases (namely $\mathrm{CBH}$ I, CBH II, and EG I) concentration within a complex hydrolyzate mixture during the varying time course of biomass saccharification. Three pretreated corn stover (CS) samples were included in this study: Ammonia Fiber Expansion ${ }^{\mathrm{a}}$ (AFEX ${ }^{\mathrm{TM}}-\mathrm{CS}$ ), dilute acid (DA-CS), and ionic liquid (IL-CS) pretreatments. The relative fraction of bound individual cellulases varied depending not only on the pretreated biomass type (and lignin abundance) but also on the type of cellulase. Acid pretreated biomass had the highest levels of non-recoverable cellulases, while ionic liquid pretreated biomass had the highest overall cellulase recovery. CBH II has the lowest thermal stability among the three $T$. reesei cellulases tested. By preparing recombinant family 1 carbohydrate binding module (CBM) fusion proteins, we have shown that family 1 CBMs are highly implicated in the non-productive binding of full-length $T$. reesei cellulases to lignin.

Conclusions: Our findings aid in further understanding the complex mechanisms of non-productive binding of cellulases to pretreated lignocellulosic biomass. Developing optimized pretreatment processes with reduced or modified lignin content to minimize non-productive enzyme binding or engineering pretreatment-specific, low-lignin binding cellulases will improve enzyme specific activity, facilitate enzyme recycling, and thereby permit production of cheaper biofuels.

Keywords: Cellulosic biofuels, Cellulase adsorption, Enzymatic saccharification, Lignin, Non-specific enzyme binding

\section{Background}

Biological-catalyzed transformation of cellulosic biomass to fuels, chemicals, and materials can address several imminent challenges faced by our society such as climate change, energy security, and rural economic development [1]. However, the transition from traditional crude oil to a biomass based economy is not simple.

\footnotetext{
* Correspondence: chundawa@msu.edu

'Department of Chemical Engineering and Materials Science, Michigan State University, East Lansing, Ml 48824, USA

${ }^{2}$ Great Lakes Bioenergy Research Center (GLBRC), Michigan State University, 164 Food Safety and Toxicology Building, East Lansing, MI 48824, USA Full list of author information is available at the end of the article
}

Lignocellulosic biomass recalcitrance to enzymatic and microbial-catalyzed deconstruction is one of the major factors hindering the production of inexpensive biofuels $[2,3]$.

Enzymatic hydrolysis of lignocellulosic biomass requires a complex suite of hydrolytic and lytic enzymes (called CAZymes or carbohydrate-active enzymes; http://www. cazy.org) that synergistically depolymerize cell wall carbohydrate polymers into fermentable monomeric sugars [4]. Cellulose is the dominant carbohydrate polymer in cell walls and consists of several hundred $\beta-1,4$ linearly linked glucose polymer chains that aggregate into fibrils (24 to 36 chains) via hydrogen bonding and van der Waals 
interactions [5,6]. These cellulose fibrils can be depolymerized into soluble sugars by a combination of cellulolytic CAZymes, including endoglucanases (EGs), cellobiohydrolases $(\mathrm{CBHs})$ or exoglucanases, and $\beta$-glucosidases $(\beta \mathrm{Gs})$ $[2,7]$. The classical mechanism for cellulose deconstruction has involved the synergistic action of EGs and CBHs, where EGs randomly hydrolyze internal glycosidic bonds in the cellulose chains while the $\mathrm{CBHs}$ processively attack the reducing or non-reducing ends of the cellulose chains. Binding of cellulases to the insoluble substrate is the essential first step towards deconstruction of cellulose to cellodextrins or glucose. CBHs and EGs typically contain a catalytic domain $(\mathrm{CD})$ and a carbohydrate binding module (CBM) $[2,8]$ joined by an extended interdomain linker peptide [9]. Previous work has suggested that the extent of binding of full-length cellulases to crystalline cellulose depends on both the CBM and the CD [10-12]. CBMs can enhance CD catalytic efficiency on insoluble substrates by increasing the local surface bound enzyme concentrations [8-10] and by targeting glycans specific to the $\mathrm{CD}[8,13]$.

In recent times, this classical endo-exo mechanism has been extended to include lytic polysaccharide monooxygenases that can oxidatively cleave cellulose glycosidic bonds instead of hydrolyzing them [4]. Nevertheless, EGs and $\mathrm{CBHs}$ remain the dominant CAZymes in commercial enzyme cocktails produced by industrial fungal strains (for example, Trichoderma reesei, now called Hypocrea jecorina) necessary to completely deconstruct pretreated cellulosic biomass into soluble sugars [14]. The minimum cocktail of T. reesei cellulases needed to hydrolyze cellulosic biomass includes EG I (Cel7B, [GenBank:M15665]; glycosyl hydrolase or GH family 7B), CBH I (Cel7A, [GenBank:CAH10320]; GH family 7A), and CBH II (Cel6A, [GenBank:M16190]; GH family 6A) [14-16]. Studies focused on optimizing the ratio of individual enzymes for pretreated biomass saccharification indicate that these three cellulases are not only critical to hydrolysis efficiency but are also the most abundant enzymes in native secretomes and optimized cocktails $(>60-70 \%$, total protein weight basis) [15,17-19]. One of the crucial issues, however, is the high enzyme loading (>20-30 mg protein/g glucan) necessary for complete biomass saccharification. This is largely due to the high abundance of crystalline cellulose fibrils [20,21], which have poor enzyme accessibility [22] by virtue of being embedded in an amorphous matrix of hemicellulose and lignin within the cell wall $[6,23]$.

Lignin is thought to impede the activity of CAZymes in part because of non-productive binding of enzymes to its surface and/or through steric hindrance due to the lignincarbohydrate complexes that decrease cellulose accessibility [22,24-33]. In addition, lignin-derived degradation products produced during pretreatment could further inhibit enzyme activity [34-36]. Recalcitrance to enzymatic saccharification is dependent on the total amount and type of lignin present within plant cell walls [37-39]. Consequently, delignification of biomass after pretreatment can enhance hydrolysis rate and overall sugar yield [33,40]. Several studies have reported on the beneficial effects of surfactants and other sacrificial proteins (like bovine serum albumin, or BSA) that likely prevent non-productive binding of cellulases to lignin to some extent [41-43]. However, the affinity of individual cellulases towards lignin is still far from clear. This is partly due to the lack of suitable techniques to track binding of individual enzymes within complex protein mixtures during biomass saccharification. Secondly, it is difficult to distinguish the contribution of productive (binding to specific glycans) versus non-productive (binding to lignin) binding of cellulases to complex lignocellulosic substrates. Conducting assays on purified cell wall components like acidinsoluble Klason lignin or pure cellulose (like Avicel ${ }^{\mathrm{m}}{ }^{\mathrm{N}}$ ) to mimic individual components of pretreated biomass is one way to address this problem $[24,44]$. However, the major limitation of this approach is that the molecular and ultrastructure of lignin is modified during the isolation process, and hence its affinity toward enzymes may not be representative of native cell wall lignin. The pretreated cell wall ultrastructure (for example, lignin relocalization during pretreatment) and chemical linkages between different cell wall components (cellulose, hemicelluloses, and lignin) also cannot be simulated by physically recombining individually purified components. Furthermore, previous approaches to track binding of cellulases to insoluble biomass during saccharification have been conducted by measuring either total crude protein concentration, individual protein concentration by SDS-PAGE, and/or activities of unbound enzymes in the hydrolyzate using individual CAZyme specific substrates $[32,33,44]$. Such approaches have several limitations that have been highlighted previously [45].

To achieve a comprehensive understanding of cellulase binding to pretreated lignocellulosic biomass during saccharification, we have utilized an FPLC-based methodology to quantify the CBH I, CBH II, and EG I free enzyme concentration within a complex hydrolyzate mixture [45,46]. Three pretreated corn stover samples were included in this study: Ammonia Fiber Expansion (AFEX-CS), dilute acid (DA-CS), and ionic liquid (IL-CS). These three pretreatment processes produce substrates with a range of residual lignin concentrations and therefore allow us to compare cellulase adsorption characteristics as a function of lignocellulose composition. We have made several interesting observations in the course of these studies: (a) The relative binding affinity of individual cellulases varied depending not only on the pretreated biomass type but also on the type of cellulase; (b) the total extent of non-productively bound cellulase to residual insoluble lignin depended on the pretreatment type and was directly correlated with lignin abundance; (c) the varying thermostability of Trichoderma reesei cellulases suggests that the composition of the 
enzymes active within the cocktail can change drastically during the course of biomass saccharification; and (d) by preparing recombinant CBM1 fusion proteins (tagged to green fluorescent protein, or GFP), we have shown that family 1 CBMs are highly implicated in non-productive binding of full-length cellulases to lignin. Overall, these findings would aid in the development of efficient, pretreatmentspecific cellulase cocktails and economic enzyme recycling options to reduce the cost of biofuel production.

\section{Results}

\section{AFEX, IL, and DA pretreated corn stover composition}

The composition of corn stover pretreated by three leading pretreatment technologies being developed at the GLBRC (Great Lakes Bioenergy Research Center), BESC (BioEnergy Science Center), and JBEI (Joint BioEnergy Institute) is shown in Table 1. AFEX-CS has almost an identical composition to that of the original untreated biomass, which was approximately $34.4 \%$ glucan, $22.4 \%$ xylan, and $11 \%$ acid-insoluble lignin (on a dry weight basis). The DA-CS sample has the least amount of xylan (3.3\%) and consequently has the highest glucan (60.6\%) and lignin (32.9\%) content. IL pretreatment selectively removes most of the lignin $(2.7 \%$ residual lignin left behind) from the CS while leaving behind the glucan (46.9\%) and xylan (29.8\%). All subsequent biomass saccharification assays were performed at $1 \%$ glucan loading (dry weight basis) so that the maximum theoretical glucose yields and total enzyme needed (mg protein/g glucan) are identical. However, maximum xylose and acidinsoluble lignin concentrations are substrate-dependent as shown in Table 1.

\section{Biomass saccharification yields and concentrations of free cellulases}

The saccharification yields and residual percentage of free cellulases bound to isolated cellulose (Avicel and amorphous cellulose), IL-CS, AFEX-CS, and DA-CS are shown in Figures 1, 2, 3, and 4, respectively. As shown previously [46], Avicel and amorphous cellulose gave greater than

Table 1 Composition of various biomass substrates and maximum expected concentration of glucose, xylose, and lignin in pretreated biomass hydrolyzates (1\% glucan loading basis) tested in this study

\begin{tabular}{lllllccc}
\hline Substrates & \multicolumn{3}{l}{ Biomass composition } & & \multicolumn{3}{c}{ Maximum concentration (g/L) } \\
\cline { 2 - 3 } \cline { 6 - 8 } & Glucan & Xylan & Lignin & & Glucose & Xylose & Lignin \\
\hline IL-CS & $46.9 \%$ & $29.8 \%$ & $2.7 \%$ & & 11.11 & 7.22 & 0.58 \\
AFEX-CS & $34.6 \%$ & $19.6 \%$ & $11.0 \%$ & & 11.11 & 5.66 & 3.18 \\
DA-CS & $60.6 \%$ & $3.3 \%$ & $32.9 \%$ & & 11.11 & 0.62 & 5.43
\end{tabular}

Compositional data are on a dry weight basis. Lignin values reported here are for acid-insoluble Klason lignin only. All analyses were carried out in triplicate with mean values reported. Standard deviations in all cases were less than $10 \%$ of the reported mean values.
$90 \%$ glucose yield after 48 and $12 \mathrm{~h}$, respectively (Figure 1 ). Since these substrates are predominantly cellulosic in composition ( $>99 \%$ on a dry weight basis), no additional assays were carried out in the presence of hemicellulases. More than $85 \%$ of CBH I, CBH II, and EG I were bound to amorphous cellulose within the first hour of saccharification. In contrast, a maximum of $35-45 \%$ of total added cellulases were bound to Avicel at an equivalent protein loading. Approximately $85-95 \%$ of the original added concentrations of all three cellulases were found in the hydrolyzate supernatant for amorphous cellulose after $12 \mathrm{~h}$ of saccharification. Similarly, close to $90 \%$ of added CBH I and EG I were found in the hydrolyzate supernatant for Avicel after $48 \mathrm{~h}$ of saccharification. Only about $60 \%$ of the initially added concentration of CBH II was recovered in the hydrolyzate for Avicel after $48 \mathrm{~h}$.

IL-CS, which had the lowest lignin and highest xylan content among all pretreated CS substrates tested, gave close to $88 \%$ glucose yield and $53 \%$ xylose yield (Figure 2) after $48 \mathrm{~h}$ of saccharification by the ternary cellulase cocktail (CBH I, CBH II, and EG I) supplemented with hemicellulases (endoxylanase, EX, and $\beta$-xylosidase, $\beta X$ ). In the absence of supplemented hemicellulases, the ternary cellulase cocktail gave close to $82 \%$ glucose yield and $12 \% \mathrm{xy}-$ lose yield after $48 \mathrm{~h}$. Around $85 \%$ of the added cellulases were bound to the pretreated substrate within $1 \mathrm{~h}$ of saccharification. With increasing hydrolysis yields, the bound enzymes slowly returned to the supernatant at varying extents depending on the cellulase type. $\mathrm{CBH}$ II was the highest recovered cellulase with nearly $62 \%$ present in the hydrolyzate after $48 \mathrm{~h}$ (when supplemented with hemicellulases). Only $30 \%$ of EG I and $47 \%$ of CBH I were released back into the supernatant after $48 \mathrm{~h}$, with little impact of hemicellulase addition on recovery of either cellulase.

AFEX-CS, which had intermediate lignin and xylan content among all the pretreated CS substrates tested, gave close to $84 \%$ glucose yield and 10\% xylose yield (Figure 3) after $48 \mathrm{~h}$ of saccharification by the ternary cellulase cocktail. Supplementation of hemicellulases increased the glucose yield to $99 \%$ and the xylose yield to $55 \%$ after $48 \mathrm{~h}$. The significant enhancement in both glucose and xylose yield for AFEX-CS upon addition of synergistic hemicellulases is consistent with our previous results $[15,47]$. As seen for IL-CS, most of the added cellulases (about 8590\%) are bound to the biomass after $1 \mathrm{~h}$ of saccharification. As the saccharification of residual cellulose and hemicellulose proceeded, a limited fraction of initially added cellulases were desorbed back into the hydrolyzate supernatant. The maximum fraction of CBH I ( $47 \%$ and $60 \%$ on added $\mathrm{CBH}$ I with and without hemicellulase supplementation, respectively) was found in the supernatant after $48 \mathrm{~h}$ of saccharification. For CBH II, a significantly lower fraction of added enzymes could be desorbed from 

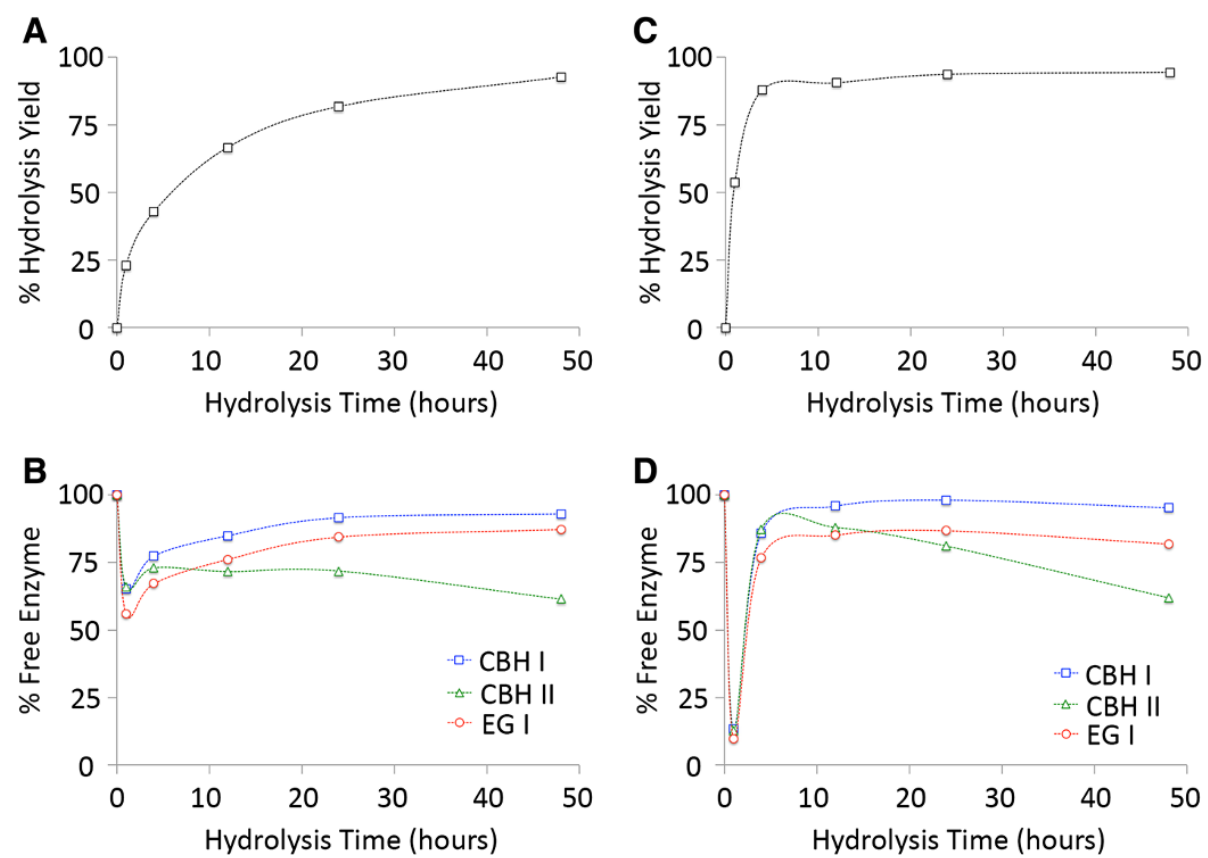

Figure 1 Hydrolysis yield $(A, C)$ of glucan to glucose and percentage of free cellulases in the hydrolyzate supernatant $(B, D)$ for crystalline (A-B) and amorphous (C-D) cellulose. Assays were carried out using a ternary cellulase cocktail of CBH I (blue squares), CBH II (green triangles), and EGI (red circles) for $48 \mathrm{~h}$ at $50^{\circ} \mathrm{C}$. All assays were carried out in triplicate with mean values reported here. Standard deviations in all cases were less than 5\%. Data for this figure have been reproduced from our previous study [46].

the biomass. Hemicellulase supplementation increased $\mathrm{CBH}$ II recovery to about $37 \%$ after 48 h. For EG I, which had the poorest recovery among all three cellulases, only $20-26 \%$ of the total added amount could be detected in the supernatant with or without hemicellulase supplementation.

DA-CS, which had the highest lignin and lowest xylan content among all pretreated CS substrates tested in this study, gave close to $88 \%$ glucose yield and $28 \%$ xylose yield (Figure 4) after $48 \mathrm{~h}$ of saccharification by the ternary cellulase cocktail. Supplementation of hemicellulases increased the glucose yield to $97 \%$ and the xylose yield to $68 \%$ after $48 \mathrm{~h}$. As seen previously [46], most of the added cellulases (about 80\%) are bound to the biomass after $1 \mathrm{~h}$ of saccharification. However, unlike all other substrates, a significant fraction of added cellulases were still not recoverable for DA-CS (about 70-90\%), even after $48 \mathrm{~h}$ of saccharification. A maximum of $30 \%$ of total added CBH I was detected in the supernatant, which is nearly half of the total recovered fraction for AFEX-CS. Approximately 20\% of EG I and 12\% of CBH II were detected in the DA-CS hydrolyzate supernatant, with minimal impact of hemicellulase addition on cellulase recovery.

\section{Relationship between cellulase recovery and total residual lignin concentration}

The total fractions of free cellulases available in the hydrolyzate after $48 \mathrm{~h}$ of saccharification by a ternary cellulase cocktail for Avicel, IL-CS, AFEX-CS, and DA-CS are plotted against respective residual lignin concentrations in Figure 5. Fitting a linear regression trend line for $\mathrm{CBH} I$ $\left(R^{2}=0.63 ;\right.$ slope $=-0.0877$; intersection $\left.=0.74\right), \quad$ CBH II $\left(R^{2}=0.99\right.$; slope $=-0.0933$; intersection $\left.=0.64\right)$, and EG I $\left(R^{2}=0.53\right.$; slope $=-0.0913$; intersection $\left.=0.62\right)$ indicates a marginal correlation between maximum recoverable cellulase fraction and total hydrolyzate lignin concentration. The $y$-axis intersection of these trend lines is not equal to unity, suggesting that the relationship between cellulase binding and lignin concentration is possibly non-linear. Other factors (such as cellulase thermal stability and lignin composition) may also play an important role in influencing cellulase recovery. The greatest drop in the recoverable fraction of cellulase with increasing lignin concentration (that is, the largest negative slope) was seen for $\mathrm{CBH}$ II > EG I > CBH I.

\section{Relationship between cellulase recovery and thermal denaturation}

To determine the thermal stability of individual purified T. reesei cellulases, individual enzymes were incubated at $50^{\circ} \mathrm{C}$ in buffer alone for varying time periods. Periodically, samples were removed and assayed to determine specific activity (Figure 6), as shown previously [46]. After $48 \mathrm{~h}$, a little over $60 \%$ of the original CBH II activity was retained. In contrast, CBH I and EG I retained more than 90-95\% of their initial activity. A noticeable drop in cellulase 


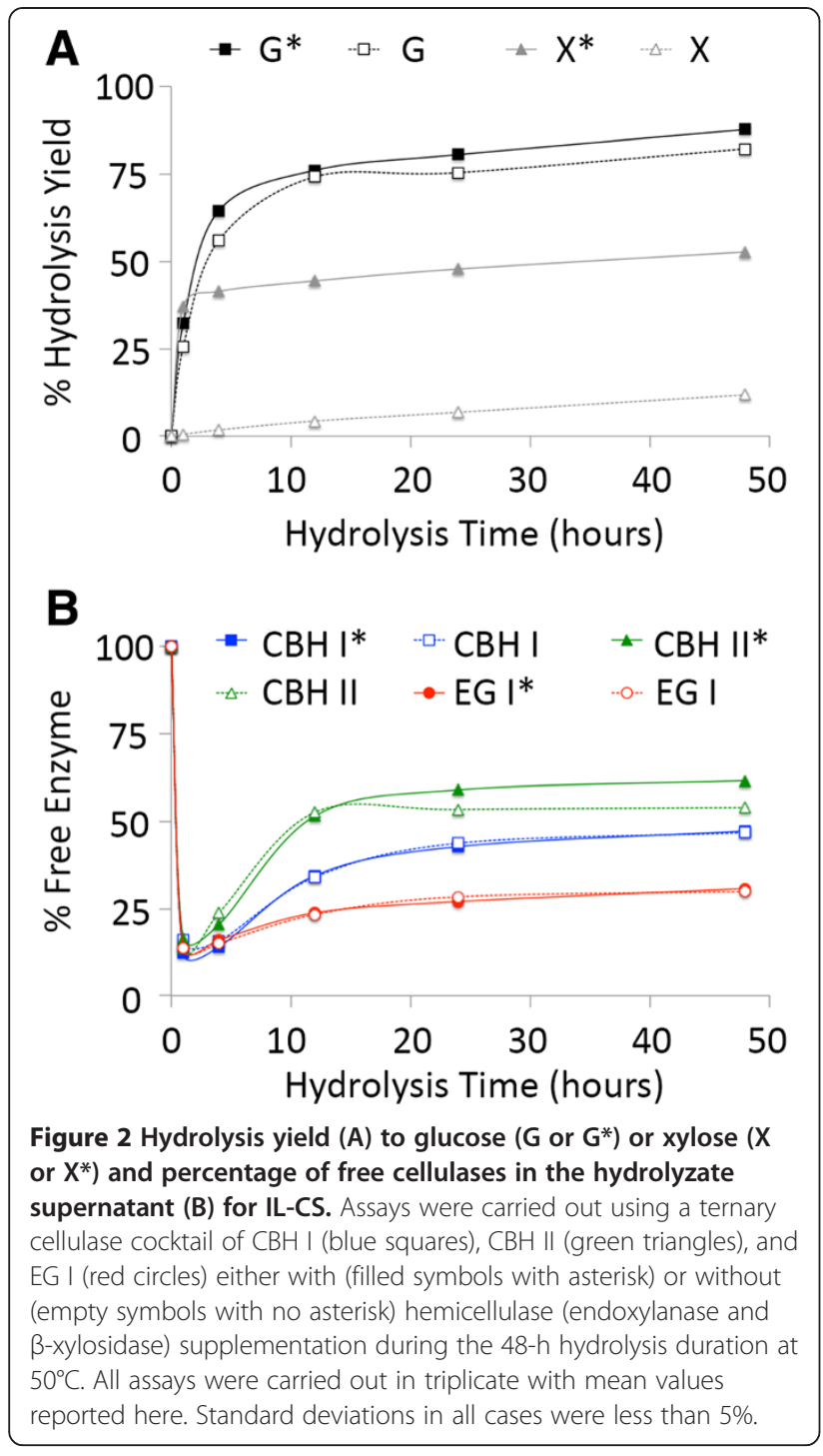

activity is seen after $12 \mathrm{~h}$ of incubation at $50^{\circ} \mathrm{C}$. These results clearly suggest that thermal denaturation of $\mathrm{CBH}$ II, as indicated by the loss in residual enzymatic activity, is likely responsible for the poor recovery during biomass saccharification as well.

\section{Role of family 1 CBM on binding full-length cellulases to lignin}

In order to understand the role of family $1 \mathrm{CBMs}$ in protein-lignin binding, CBM1 from Trichoderma reesei $\mathrm{CBH}$ I (Cel7A) was expressed as a genetic fusion to GFP (GFP-CBM1). GFP-CBM1 and a control GFP construct were prepared, and their relative binding to AFEX-CS derived lignin (>90\% acid-insoluble Klason lignin; dry weight basis) was determined (Figure 7). In this assay, $0.2 \mu \mathrm{M}$ of protein was incubated in the presence of different lignin concentrations at $\mathrm{pH} 6.0$ in phosphate buffered saline. After $1 \mathrm{~h}$ of incubation, the amount of protein adsorbed
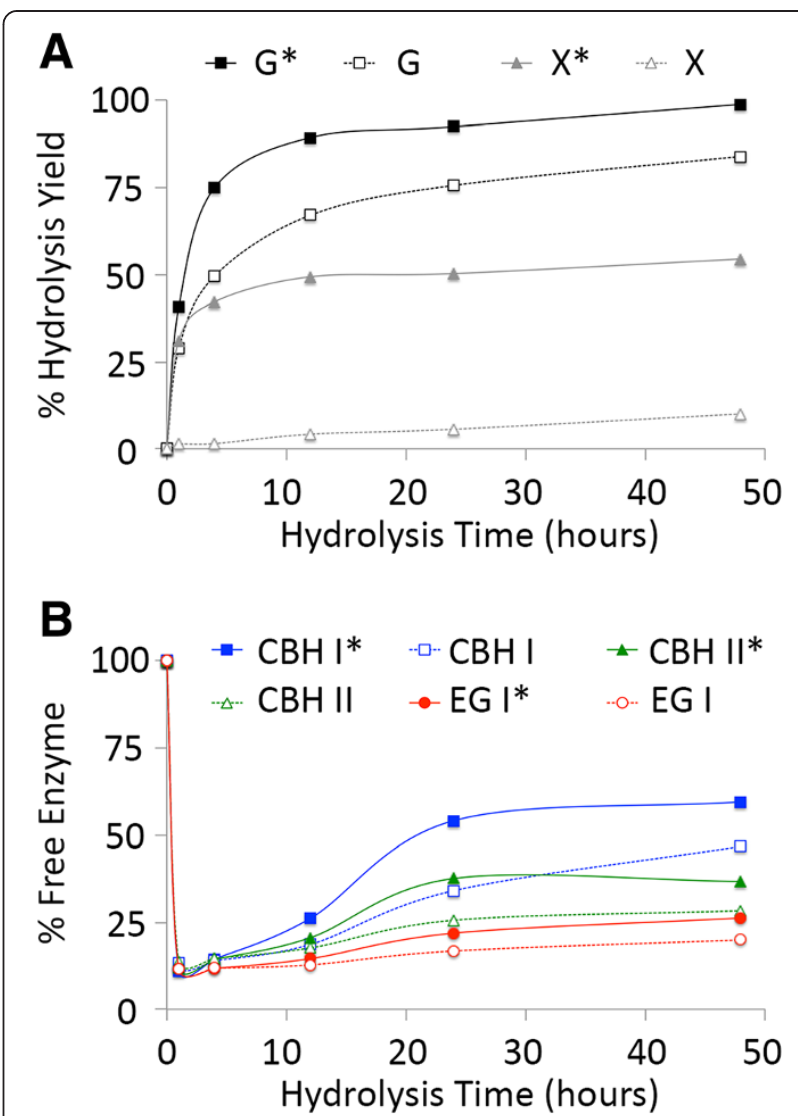

Figure 3 Hydrolysis yield $(A)$ to glucose $\left(G\right.$ or $G^{*}$ ) or xylose (X or $\left.X^{*}\right)$ and percentage of free cellulases in the hydrolyzate supernatant (B) for AFEX-CS. Assays were carried out using a ternary cellulase cocktail of CBH I (blue squares), CBH II (green triangles), and EG I (red circles) either with (filled symbols with asterisk) or without (empty symbols with no asterisk) hemicellulase (endoxylanase and $\beta$-xylosidase) supplementation during the $48-h$ hydrolysis duration at $50^{\circ} \mathrm{C}$. All assays were carried out in triplicate with mean values reported here. Standard deviations in all cases were less than 5\%. Data for this figure have been reproduced from our previous study [46]

onto lignin was recorded. At all concentrations, there is a significant difference in the binding of GFP-CBM1 versus the GFP control (as indicated by \% relative fluorescence units, or RFU, lost in the supernatant) to lignin. At saturation, approximately $95 \%$ of the added GFP-CBM1 was bound to the insoluble lignin compared to $55 \%$ bound GFP control. These results suggest that the presence of a type A, family $1 \mathrm{CBM}$ corresponds to an increase in protein-lignin binding, even at lignin concentrations as low as $0.5 \mathrm{~g} / \mathrm{L}$.

\section{Predicted hydrophobic patch scoring for cellulases using Rosetta}

To gain a better understanding of the increased binding of CBMs to lignin and variations in the binding behavior for different full-length cellulases, we computationally 

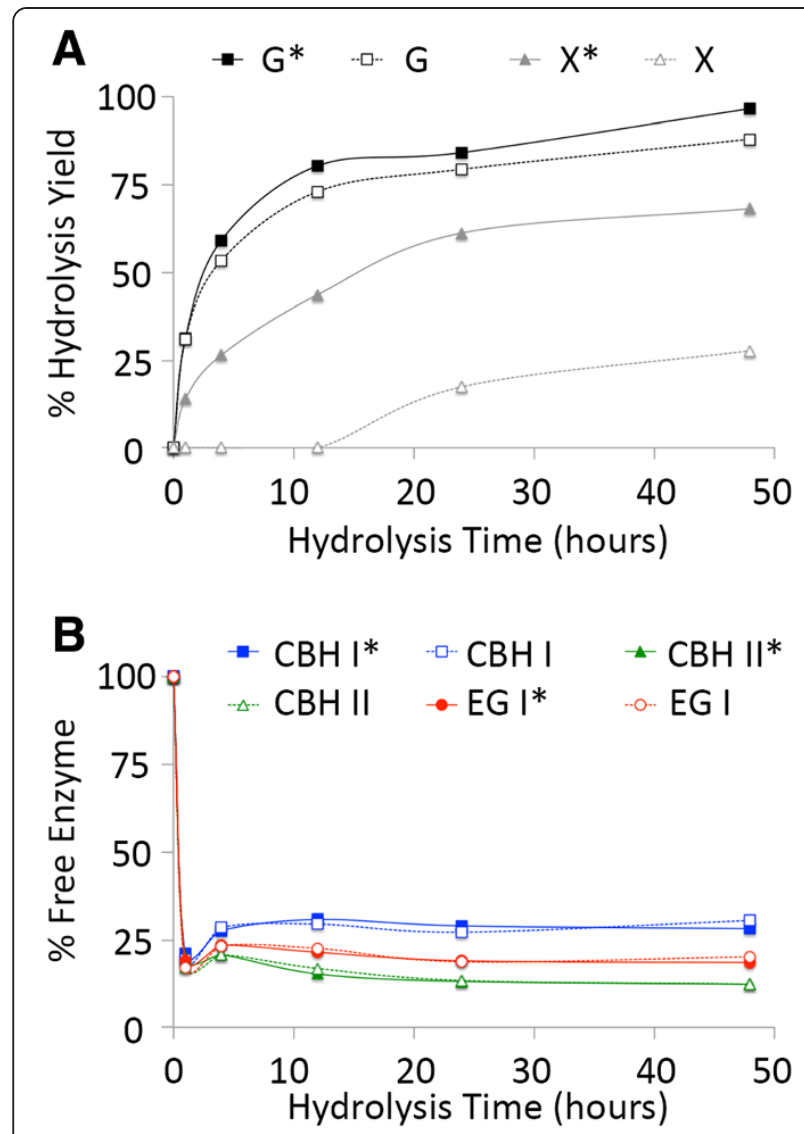

Figure 4 Hydrolysis yield (A) to glucose (G or $\mathrm{G}^{*}$ ) or xylose (X or $\left.\mathrm{X}^{*}\right)$ and percentage of free cellulases in the hydrolyzate supernatant (B) for DA-CS. Assays were carried out using a ternary cellulase cocktail of CBH I (blue squares), CBH II (green triangles), and EG I (red circles) either with (filled symbols with asterisk) or without (empty symbols with no asterisk) hemicellulase (endoxylanase and $\beta$-xylosidase) supplementation during the $48-h$ hydrolysis duration at $50^{\circ} \mathrm{C}$. All assays were carried out in triplicate with mean values reported here. Standard deviations in all cases were less than 5\%.

determined the overall protein surface hydrophobicity for our experimentally tested constructs using the hydrophobic patch score in Rosetta [25]. This scoring term predicts significant enzyme-lignin binding for each of the three cellulases (Table 2). Previous work suggests a direct correlation between enzyme hydrophobic patch score and its binding to lignin [25]. The patch scores for full-length enzymes predict that EG I should have the lowest binding (Table 2), while CBH II should have the highest binding. Scoring the individual catalytic domains of each enzyme verifies the same rank order.

\section{Discussion}

By tracking the dynamic interaction of a minimal set of cellulases with various pretreated biomass substrates during saccharification, our experiments have revealed the relationship between enzyme recoverability and residual lignin

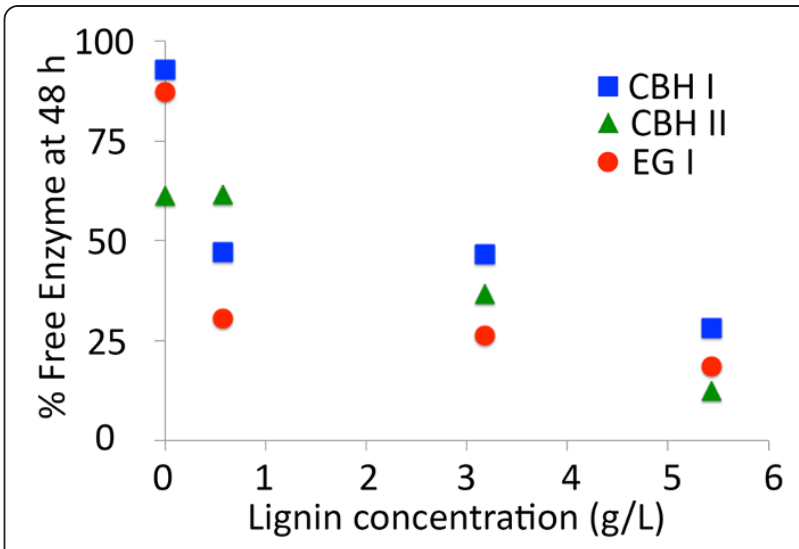

Figure 5 Free cellulase concentration in the hydrolyzate supernatant as a function of total lignin concentration. Data for free CBH I (blue squares), CBH II (green triangles), and EG I (red circles) after 48-h saccharification of Avicel (0 g/L lignin), IL-CS (0.58 $\mathrm{g} / \mathrm{L}$ lignin), AFEX-CS (3.18 g/L lignin), and DA-CS (5.43 g/L lignin) at $50^{\circ} \mathrm{C}$ are reported here. All assays were carried out in triplicate with mean values shown here. Standard deviations in all cases were less than $5 \%$.

concentration of the substrate. The current sets of experiments were carried out using a ternary cellulase cocktail (CBH I, CBH II, and EG I) with and without hemicellulase supplementation. Previous work has shown that the minimal ternary cellulase cocktail comprises close to $80 \%$ by mass of the total added enzymes necessary for complete cellulose saccharification $[15,18,47]$. However, for substrates like AFEX-CS and IL-CS, other auxiliary hemicellulases are necessary to achieve high hemicellulose hydrolysis yields [40].

For DA-CS and IL-CS, hemicellulase addition does not impact cellulase recovery. However, for AFEX-CS there is

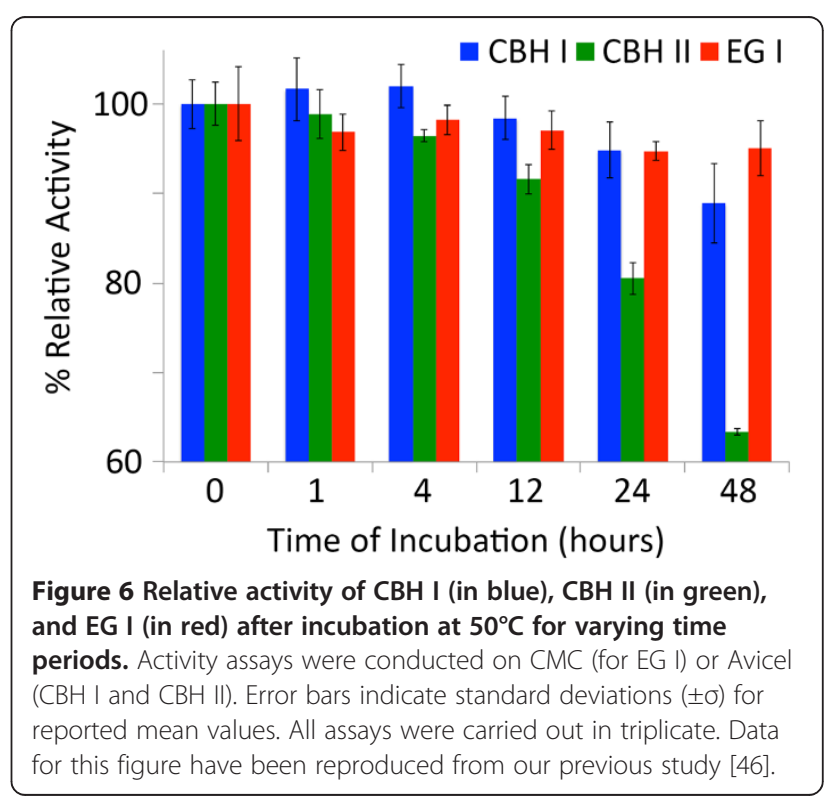




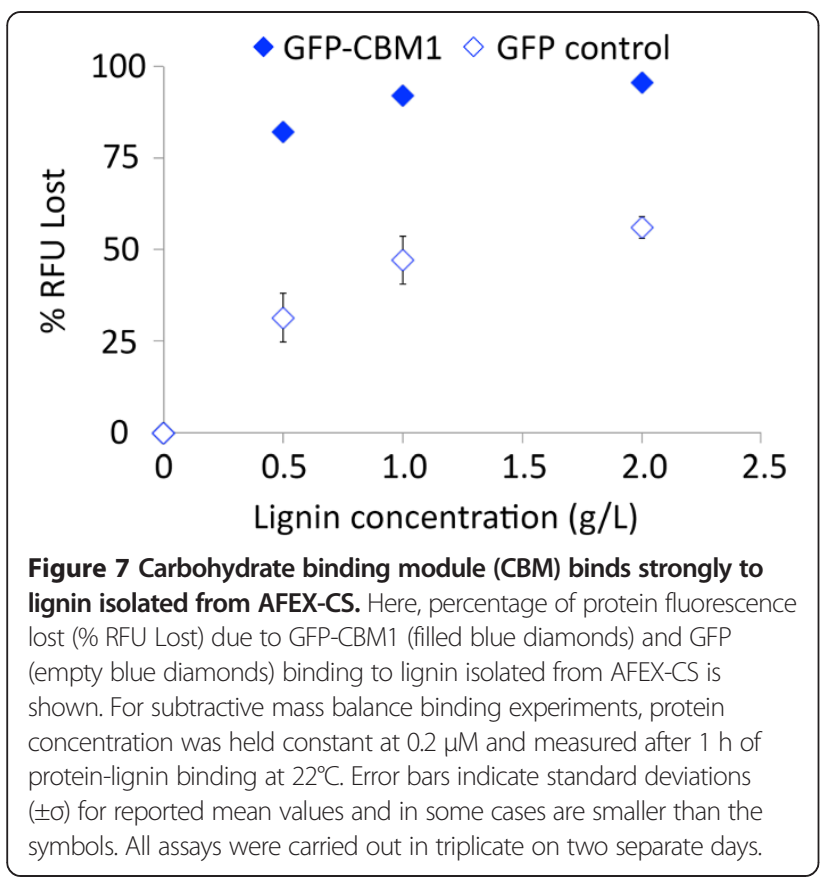

a significant improvement of cellulase recovery when hemicellulases are added. Because the gross hemicellulose composition of IL-CS is similar to AFEX-CS, it is possible that ultrastructural organizational differences in the xylan and cellulose might explain the improvement of cellulase recovery in the AFEX-CS case. AFEX pretreatment has been shown to remove some amount of hemicellulose along with alkali soluble lignin and redeposit it on the outer cell wall surface [23]. However, unlike for ILs, concentrated ammonium hydroxide used during AFEX does not swell or disrupt cellulose fibrils considerably to facilitate complete hemicellulose removal and precipitation [48]. A significant

\begin{tabular}{|c|c|}
\hline & Unweighted hydrophobic patch score \\
\hline Full-length EG I & 6.8 \\
\hline Full-length CBH I & 13.3 \\
\hline Full-length CBH II & 27.9 \\
\hline$E G \mid C D$ & 6.2 \\
\hline $\mathrm{CBH} I \mathrm{CD}$ & 6.7 \\
\hline $\mathrm{CBH} \| \mathrm{CD}$ & 23.7 \\
\hline $\mathrm{EG} \mid \mathrm{CBM}$ & 0.6 \\
\hline $\mathrm{CBH}$ I CBM & 6.6 \\
\hline CBH ॥ CBM & 4.2 \\
\hline
\end{tabular}

Structures were downloaded from the Protein Data Bank (PDB), modeled if necessary, and scored in Rosetta as described in the Methods section. Previous literature demonstrates that significant protein-lignin binding correlates with unweighted hydrophobic patch scores over 5 [25]. All full-length cellulases tested exceed this threshold. fraction of poorly accessible hemicellulose is interlaced between cellulose microfibrils $[5,6]$ in native and AFEX treated cell walls [23]. It is therefore likely that this residual hemicellulose may be responsible for preventing complete cellulose saccharification and facilitates nonproductive interactions with core cellulases. This could explain why the addition of hemicellulases that can hydrolyze and remove the residual hemicellulose has a greater impact on the recovery of core cellulases for AFEX-CS but not IL-CS. More research is clearly needed to better understand the impact of ILs on hemicellulose ultrastructure and lignin-hemicellulose complexation.

The net recoverability of the cellulase following $48 \mathrm{~h}$ of saccharification was closely dependent on the type of cellulase as well as the pretreatment chemistry. CBH I had the highest recovery for AFEX-CS and DA-CS, but surprisingly CBH II had the highest recovery for IL-CS after $48 \mathrm{~h}$. This suggests that not only is the net lignin content influencing the total recovery of cellulases, but perhaps it is influencing the physical and chemical states of the lignocellulosic substrate as well. ILs are known to acetylate lignin, modify the syringyl-to-guaiacyl ratio, and decrease lignin ether content [49]. DA pretreatments can not only hydrolyze hemicellulose to soluble oligomers, but also result in cleavage of lignin ether linkages, acid-catalyzed lignin condensation, and formation of high surface area lignin nanoglobules [50]. AFEX pretreatment results in the cleavage of ester linkages with minimal modification of core lignin but can also form lignin-enriched globules [23]. Reducing the hydrophobicity of lignin by acetylation during IL pretreatment could explain the increased recoverability of CBH II, although more research is needed to rigorously test this hypothesis.

Although the rank order of cellulase-lignin binding predicted by hydrophobic patch score is not directly reflected in our experiments, all three cellulases contain significant hydrophobic patches predicted to impact enzyme-lignin binding [25]. However, the experimental results suggest that hydrophobic surface patches are not the sole contributing factor to lignin-mediated enzyme inactivation during hydrolysis. Previous work has shown that modification of lignin hydrophobicity can impact interaction of cellulases with lignin $[25,29,51]$. In the case of AFEX-CS and IL-CS, both exocellulases (CBH I and CBH II) had higher recovery after $48 \mathrm{~h}$ compared to EG I. We speculate that the increased non-productive interaction of endocellulases like EG I towards lignin could be due to the more open-cleft active site accessibility of aromatic amino acid residues that facilitates hydrophobic interaction with lignin [24]. More experimental evidence is needed to support this hypothesis. Previous research on optimization of the purified CAZyme cocktails for AFEX-CS has shown that EG I was required in greater proportions (nearly one-third of total enzyme added) than other enzymes for maximizing sugar 
yields [15]. Lower recovery of EG I versus exo-cellulases could explain why the optimal cocktail was skewed towards greater EG I content. These results indicate that nonproductive interactions of enzymes with lignin (that lead to enzyme denaturation and likely irreversible precipitation due to lignin) can severely limit availability of free enzymes for efficient biomass saccharification. Previous work that focused on optimizing CAZyme cocktails to maximize pretreated biomass hydrolysis yields does not currently account for the relative stability of the enzymes tested in the presence or absence of lignin $[15,17,47,52,53]$. Our results suggest that, in addition to determining which CAZymespecific activities are critical to maximizing the efficiency of the enzyme cocktail, it is also important to determine which enzymes are prone to denaturation and/or nonproductive binding to residual lignin for each type of pretreated substrate.

Trichoderma reesei cellulases (namely exo-cellulase CBH II) are known to have poor thermal stability under process relevant conditions (at $\mathrm{pH} 5,50^{\circ} \mathrm{C}$, and with shaking) $[54,55]$ and this finding was also confirmed in our recent work [46]. Thermally induced denaturation of exocellulases has been shown to be driven by aggregation and precipitation that resulted in reduced soluble protein concentration [56]. Binding of proteins to hydrophobic surfaces can further trigger conformational changes that drive enzyme denaturation as well [57]. This poor thermal stability is reflected in the lower net recoverable fraction of CBH II after completion of saccharification of Avicel and amorphous cellulose (hemicellulose and lignin are absent here unlike other substrates) compared with the other two cellulases. These results also suggest that drawing conclusions regarding reversibility of CAZymes binding to cellulose or lignocellulose based on free protein concentrations in the supernatant alone may have been premature, since protein precipitation due to poor thermal stability is likely unaccounted for in most depletion-based binding assays $[24,58]$.

We have also shown that family 1 carbohydrate binding modules (CBM1 from CBH I) based GFP fusion proteins have higher relative affinity to AFEX-CS-derived acid-insoluble lignin compared to the GFP only control. Since all Trichoderma cellulase-derived CBMs belong to family 1 and are known to have a high pairwise sequence identity [59], we expect similar binding behavior for CBMs from CBH II and EG I to lignin. Previous work has suggested that CBMs and their hydrophobic aromatic amino acid residues facilitate non-productive cellulase binding to lignin in a $\mathrm{pH}$-dependent manner $[24,60]$. Though the relative contribution of electrostatic versus hydrophobic interactions between cellulaselignin cannot be clarified at this point in time [24,60], our results suggest that CBMs play an important role in triggering irreversible enzyme adsorption of full-length cellulases with residual lignin present within different pretreated substrates.

Overall, these findings allow a more detailed view of the mechanism of cellulase deactivation during lignocellulosic biomass saccharification and highlight the critical role of lignin towards facilitating this process. Decreasing cellulase cost in the overall production process centers on minimizing the role of lignin in promoting irreversible enzyme loss. From a pretreatment engineering standpoint, it would be critical to either remove lignin during pretreatment or chemically modify it to reduce its non-productive interaction with cellulases $[26,61]$. Alternatively, the cellulases could be engineered to minimize non-productive interactions with lignin while maintaining or improving specific activity and thermostability. Together, these efforts can synergistically reduce the high cost high of enzymatic saccharification for production of cellulosic fuels and chemicals.

\section{Conclusions}

Here, we have determined the total recoverable core cellulases (CBH I, CBH II, and EG I) released into the hydrolyzate supernatant following pretreated biomass saccharification. The substrates tested here were pretreated by three of the leading pretreatment technologies (IL, DA, and AFEX pretreatments) currently under investigation by US Department of Energy (DOE) bioenergy research centers. Net recovery of core cellulases following complete saccharification of pretreated biomass was inversely related to the residual biomass lignin content. Acid pretreated biomass had the highest levels of non-recoverable cellulases, while IL pretreated biomass (with minimal lignin content) had the highest cellulase recovery, especially for thermally sensitive $\mathrm{CBH}$ II. Furthermore, non-productive interaction of CBM1 to residual lignin present within pretreated lignocellulosic biomass was implicated as a major factor triggering the poor recoverability of full-length core cellulases. Future work should focus on improving the recoverability of core cellulases to help increase enzyme specific activity and facilitate enzyme recycling for realistic lignocellulosic biorefinery substrates.

\section{Methods}

\section{Crystalline and amorphous cellulose}

Avicel (PH 101, Sigma-Aldrich, St. Louis, MO), which is predominantly cellulose in composition, was used to prepare amorphous cellulose using $83 \%$ phosphoric acid at $4{ }^{\circ} \mathrm{C}$ for $60 \mathrm{~min}$ based on published protocols $[21,46,62]$. The cellulose crystallinity index for Avicel was estimated by the amorphous subtraction method, as described elsewhere [21], to be approximately $70 \%$.

\section{AFEX pretreated corn stover (AFEX-CS)}

A detailed protocol for preparing AFEX-CS has been provided previously $[45,46]$ and is reproduced here. Milled 
CS was harvested in 2002 at Wray, Colorado (Pioneer Hybrid seed variety 33A14) and generously provided by the National Renewable Energy Laboratory (NREL, Golden, CO). The milled CS was AFEX pretreated at $60 \%$ moisture ( $\mathrm{kg}$ water $/ \mathrm{kg}$ dry biomass) and 1:1 ammonia (1 $\mathrm{g}$ ammonia/g dry biomass) loading at $130^{\circ} \mathrm{C}$ for $15 \mathrm{~min}$ total residence time. Details of the AFEX protocol and equipment used are provided elsewhere $[34,63]$. AFEX-CS, after air-drying in a hood overnight, was milled (Centrifugal mill ZM 200, Retsch, Newtown, PA) using a 0.08-mm sieve attachment as described previously [64]. The biomass composition (glucan, xylan, acid-insoluble lignin) was estimated based on the standard NREL laboratory analytical procedure (LAP) protocols (http://www.nrel. gov/biomass/analytical_procedures.html).

\section{Dilute acid pretreated corn stover (DA-CS)}

A detailed protocol for preparing DA-CS has been provided previously [45] and is reproduced here. DA pretreatment was performed (at Professor Wyman's lab at the University of California, Riverside) with a 1.0 L Parr reactor made of Hastelloy C (Parr Instruments, Moline, IL, USA). The CS was presoaked in $1.0 \% \mathrm{w} / \mathrm{v}$ dilute sulfuric acid solution at $5.0 \%$ solids $(\mathrm{w} / \mathrm{w})$ overnight. The total weight of the pretreatment mixture was $800 \mathrm{~g}$. The presoaked slurry was transferred into the reactor, which was then sealed and fitted to the impeller driver motor, which was set at $150 \mathrm{rpm}$. The vessel was lowered into a hot sand bath and heated rapidly (within $2 \mathrm{~min}$ ) to an internal temperature of $140 \pm$ $2^{\circ} \mathrm{C}$ and maintained at $140 \pm 2^{\circ} \mathrm{C}$ in the fluidized heating sand bath for $40 \mathrm{~min}$. At the end of the reaction time, the reactor was cooled to below $50^{\circ} \mathrm{C}$ in a water bath. The diluted acid pretreated CS slurry was filtered through Whatman Grade Number 1 filter paper. Details of the apparatus, experimental procedure, and combined severity calculation are described elsewhere [65,66]. After pretreatment, the DA-CS residual solids were washed with water until neutral $\mathrm{pH}$ was achieved, dried at room temperature in a fume hood, milled using a 0.08- $\mathrm{mm}$ screen (as described above), and stored at $4^{\circ} \mathrm{C}$. The composition of the DA-CS residual solids was estimated based on the standard NREL LAP protocol discussed above.

\section{Ionic liquid pretreated corn stover (IL-CS)}

The IL pretreated CS was a generous gift from JBEI, and a detailed protocol for pretreatment is provided elsewhere [67]. Briefly, the CS was pretreated with 1-ethyl-3-methylimidazolium acetate at $140^{\circ} \mathrm{C}$ for $3 \mathrm{~h}$ at $10 \%(\mathrm{w} / \mathrm{w})$ solids loading. Deionized water was added to the IL-biomass slurry to recover the dissolved polysaccharides, and the slurry was washed extensively to remove residual IL to recover the IL-CS. The composition of the IL-CS residual solids was estimated based on the standard NREL LAP protocol discussed above.

\section{Hydrolytic enzyme production and purification}

Details of cellulase purification for CBH I, CBH II, and EG I are provided elsewhere [15]. Accellerase $1000^{\text {max }}$ from Genencor (Danisco US Inc., Genencor Division, Rochester, NY) was used to isolate CBH I, CBH II, and EG I. Details regarding production and purification of other enzymes used in this study (EX, $\beta \mathrm{G}, \beta \mathrm{X})$ are provided elsewhere [15]. The protein concentration was determined colorimetrically using the bicinchoninic acid or BCA protein assay kit (Pierce Biotechnology, Rockford, IL, USA) with bovine serum albumin (BSA) as the standard.

\section{Enzymatic hydrolysis}

All hydrolysis experiments were performed in a $2.2-\mathrm{mL}$ deep well microplate (Lot 780271, Greiner, Monroe, NC) at $1 \%(\mathrm{w} / \mathrm{w})$ glucan loading along with $50 \mathrm{mM} \mathrm{pH} 4.5$ citrate buffer in a total reaction volume of $500 \mu \mathrm{L} .15 \mathrm{mg} / \mathrm{g}$ glucan (corresponding to $0.15 \mathrm{mg} / \mathrm{mL}$ ) each of CBH I, $\mathrm{CBH}$ II, and EG I were loaded along with $2 \mathrm{mg} / \mathrm{g}$ glucan of $\beta G$ to prevent buildup of cellobiose. In addition, the ternary cellulase cocktails were supplemented with endoxylanase or EX ( $5 \mathrm{mg} / \mathrm{g}$ glucan) and beta-xylosidase or $\beta X$ ( $2 \mathrm{mg} / \mathrm{g}$ glucan) to achieve near-theoretical glucan conversions within $48 \mathrm{~h}$. The microplates were incubated at $50^{\circ} \mathrm{C}$ with shaking at $250 \mathrm{rpm}$ for $48 \mathrm{~h}$. Sampling was conducted at 1, 4, 12, 24, and $48 \mathrm{~h}$. The supernatant was then separated from the insoluble solids by filtering through a $0.45-\mu \mathrm{m}$ low protein binding hydrophilic microplate based filter (Lot R6PN00144, Millipore, Ireland) for protein and sugar analysis. All experiments were carried out in triplicate with mean values and standard deviations as reported in the figures. Glucose and xylose concentrations within the hydrolyzate were analyzed by HPLC as reported previously $[34,46]$.

\section{Quantitation of free CBH I, CBH II, and EG I in hydrolyzate supernatant}

The detailed methodology for individual cellulase quantification is published elsewhere $[45,46]$ and is reproduced here. The difference in isoelectric points for CBH I, CBH II, and EG I allows them to differentially bind to an anion exchange column (Mono Q, Lot 17-5179-01, GE Healthcare) and elute out as individual components by applying a linear gradient of $1 \mathrm{M} \mathrm{NaCl}$ at $\mathrm{pH}$ 7.5. The concentration of individual enzymes was correlated to the elution peak area detected at UV $280 \mathrm{~nm}$ and calculated using the Unicorn 5.11 software. Before injecting the hydrolyzate (originally at $\mathrm{pH} 4.5$ ) into the ion exchange column, a preliminary gel filtration step was applied to remove low molecular weight components that have UV absorbance as well as perform buffer exchange (to $\mathrm{pH}$ 7.5) [45]. Additional enzymes ( $\beta G, E X$, and $\beta X)$ were not quantified in this study. Since their molecular weights ( $\beta G$ and $\beta X$ have $\mathrm{Mw}>120 \mathrm{kDa}$ and EX $\mathrm{Mw}<25 \mathrm{kDa}$ ) are significantly 
different from those of CBH I, CBH II, and EG I (50 to 80 $\mathrm{kDa}$ ), they do not interfere with the quantification of cellulases using this method [15]. The binding behaviors for $\beta G, E X$, and $\beta X$ on a Mono $Q$ column are different compared to $\mathrm{CBH}$ I, CBH II, and EG I. Hence, trace amounts of $\beta G, E X$, and $\beta X$ in the cocktail do not affect the CBH I, $\mathrm{CBH}$ II, and EG I analysis. To reconfirm this, control experiments with and without $\beta G, E X$, and $\beta X$ along with a cellulase cocktail (CBH I, CBH II, and EG I) were run, and no interference was found (data not shown).

\section{Thermal stability of CBH I, CBH II, and EG I}

Detailed protocols for the thermal stability assays have been provided previously [46]. Briefly, $0.15 \mathrm{mg} / \mathrm{mL}$ of the individual cellulases were incubated at $50^{\circ} \mathrm{C}$ in buffer alone. Samples taken after varying incubation time periods were evaluated for cellulase specific activities on various substrates (CBH I and CBH II were tested on Avicel with incubation at $50^{\circ} \mathrm{C}$ for $24 \mathrm{~h}$; EG I was tested on carboxymethyl cellulose with incubation at $50^{\circ} \mathrm{C}$ for $1 \mathrm{~h}$ ). The reducing sugars were measured using a modified 3,5-dinitrosalicylic acid (DNS)-based assay [15]. Relative activities are reported based on samples from $0-\mathrm{h}$ incubation.

\section{Lignin extraction}

Lignin was extracted from milled AFEX-CS using established procedures [68]. Briefly, samples were extracted using a $90 \%(\mathrm{v} / \mathrm{v})$ dioxane-nanopure water mixture with a solvent-to-biomass ratio of $20 \mathrm{~mL}$ solvent per g dry weight biomass. A metal heating mantle was used to hold this reaction at boiling under nitrogen atmosphere for $1 \mathrm{~h}$. Product was filtered and neutralized before being concentrated to $20 \mathrm{~mL}$ using a rotary evaporator (Buchi, New Castle, DE, USA). To precipitate the lignin, the concentrated product was precipitated into $200 \mathrm{~mL}$ of stirring water. To remove residual dioxane, the lignin precipitate was washed extensively using $\mathrm{pH}$ 6.0 PBS buffer as follows: the precipitate was suspended in a tenfold volume of buffer and centrifuged, and the supernatant was decanted. Ten washing steps were performed for each extracted lignin sample. The composition of the extracted lignin was determined using the NREL LAP compositional analysis protocol (http://www.nrel.gov/biomass/analytical_procedures.html). Approximately 10\% of the total biomass was extracted as purified lignin.

\section{Production of GFP-CBM and GFP protein constructs}

A detailed map and protocols used for creating the generic pEC GFP_CBM plasmid are described elsewhere [69]. To generate the GFP_CBM1 construct, a family 1 CBM (from CBH I or Cel7A) was linked together via a 40 amino acid linker to GFP on the C-terminus and a $\mathrm{His}_{8}$ tag on the N-terminus. The CBM1 gene was synthesized by Genscript (Piscataway, NJ) and was inserted into an in-house pEC GFP_CBM vector using AflII and BamHI restriction enzymes, as documented elsewhere [69]. The plasmid was transformed into Rosetta-gami 2 [DE3] competent cells (Novagen, Santa Clara, CA) and inoculated into $50 \mathrm{~mL}$ non-inducing medium [70] with $50 \mu \mathrm{g} / \mathrm{mL}$ kanamycin and $25 \mu \mathrm{g} / \mathrm{mL}$ chloramphenicol. The culture was incubated overnight at $25^{\circ} \mathrm{C}$ and was used to inoculate $2 \mathrm{~L}$ of auto-induction medium. Cells were grown at $25^{\circ} \mathrm{C}$ for $27 \mathrm{~h}$. Cells were harvested using centrifugation, and the cell pellets were stored at $-80^{\circ} \mathrm{C}$.

The cell pellets were thawed and resuspended in $50 \mathrm{mM}$ Tris- $\mathrm{HCl}$ buffer with $50 \mathrm{mM} \mathrm{NaCl}$ and $15 \mathrm{mM}$ imidazole (pH 7.4) with $0.5 \mu \mathrm{L} / \mathrm{mL}$ DNAse, $0.5 \mu \mathrm{L} / \mathrm{mL}$ lysozyme, and $1 \mu \mathrm{L} / \mathrm{mL}$ protease inhibitor. Cells were sonicated with an ultrasound sonicator (550 Sonic Dismembrator, Fisher Scientific, Pittsburgh, PA) fitted with a 1 -inch probe at $4^{\circ} \mathrm{C}$ for 5 min with 30-s on bursts and 30-s off bursts. The cell debris was centrifuged at $14,000 \mathrm{rpm}$ at $4^{\circ} \mathrm{C}(20 \mathrm{~min})$ and the supernatant was collected for purification. The supernatant was purified using Ni-affinity column-based purification on an FPLC system (GE Healthcare, Pittsburgh, PA) as described previously [69]. While the GFP control protein did not require additional purification following the Ni-affinity step, the full-length GFP-CBM1 did require additional cleanup as discussed below.

To separate cleaved GFP subunits from the intact fulllength GFP-CBM protein, a modified cellulose affinity purification step was employed [71,72]. Briefly, phosphoric acid swollen cellulose (PASC) or amorphous cellulose was produced according to previously outlined protocols $[21,46,62]$. The Ni-affinity purified crude protein mixture was applied to PASC at a ratio of $200 \mathrm{mg}$ protein per g PASC (dry weight basis). This was incubated at room temperature with $150 \mathrm{rpm}$ shaking. The sample was centrifuged at $4,000 \mathrm{rpm}$ for $20 \mathrm{~min}$ at $4^{\circ} \mathrm{C}$ and the supernatant was discarded. One part pellet was resuspended with four parts (volume basis) $1 \mathrm{M} \mathrm{NaCl}$, $10 \mathrm{mM}$ MES, pH 6.0 and centrifuged again. One part pellet was resuspended with four parts (volume basis) ethylene glycol at room temperature with $150 \mathrm{rpm}$ shaking and was centrifuged again. The supernatant was collected and was concentrated on the FPLC using a Niaffinity purification column, as documented above. The eluted protein was desalted into $\mathrm{pH}$ 6.0 PBS. Protein concentrations were determined by measuring $\mathrm{A}_{448}$ of the chromophore using the $\mathrm{NaOH}$ denaturation method [73]. All chemicals were purchased from Sigma-Aldrich (St. Louis, MO), unless stated otherwise.

\section{Protein-lignin binding assay}

A fluorescence-based subtractive mass balance assay was used to characterize proteins for lignin binding. Fluorescent proteins were assayed for lignin binding with dioxaneextracted AFEX-CS lignin of $95 \%$ purity. This assay was 
performed in 1-mL deep well plates (Lot 1896-1000, USA Scientific, Orlando, FL) sealed with thermoplastic elastomer capmats (Lot 1775-3083, USA Scientific, Orlando, $\mathrm{FL}$ ). The 400- $\mu \mathrm{L}$ reaction volume comprised purified protein and extracted lignin, both in $\mathrm{pH}$ 6.0 PBS. The protein concentration was held constant at $0.2 \mu \mathrm{M}$ in the reaction for all lignin concentrations tested $(0 \mathrm{mg} / \mathrm{mL}, 0.5 \mathrm{mg} / \mathrm{mL}$, $1.0 \mathrm{mg} / \mathrm{mL}$, and $2.0 \mathrm{mg} / \mathrm{mL}$ ). Samples were incubated for $1 \mathrm{~h}$ at $22^{\circ} \mathrm{C}$. To ensure mixing between protein and lignin, end-over-end mixing via a bench top tube rotator (Argos Technologies, Elgin, IL) was used. Protein stability was accounted for by including unshaken samples at $4^{\circ} \mathrm{C}$ and $22^{\circ} \mathrm{C}$ and was also used to determine expected initial concentration. After $1 \mathrm{~h}$ of incubation, the samples were centrifuged and their supernatant collected. The fluorescence of the supernatant was measured using the Synergy H1 Hybrid Multi-Mode Microplate Reader from BioTek, Winooski, VT. Reader conditions were as follows: $481 \mathrm{~nm}$ excitation, $509 \mathrm{~nm}$ emission, gain of 50, and read height of $7.0 \mathrm{~mm}$. The unshaken controls were used to estimate the fraction of lignin bound proteins for all samples. Comparing supernatant fluorescence to the signal in the $0 \mathrm{mg} / \mathrm{mL}$ lignin loading condition gives the fraction of protein lost due to lignin binding. Experiments were carried out in triplicate on two separate days.

\section{Hydrophobic patch scoring}

Individual domains and full-length $T$. reesei cellulase structures were scored using the unweighted hydrophobic patch score term in Rosetta, as previously developed $[25,74]$. Biologically relevant versions of cellulase catalytic domains for EG I, CBH I, and CBH II from T. reesei were found in the Protein Data Bank [PDB:1eg1, 1cel, and 1hgw, respectively]. CBMs for CBH I [PDB:1cbh] and EG I [PDB:4bmf] were scored from previously solved structures. The structure for $\mathrm{CBH}$ II CBM was generated from the $\mathrm{CBH}$ I scaffold using the mutagenesis wizard in PyMOL [75] with the following mutations: T1C, Q2S, H4V, Y5W, I11Q, G12N, Y13W, V18C, T23S, Q26V, V27Y, L28S, P30D. All structures were cleaned and renumbered before the analysis in Rosetta. Validation of the hydrophobic patch scoring term with the results of Sammond and co-workers [25] was done by rescoring BSA.

\section{Endnote}

${ }^{a} A F E X$ is a trademark of MBI, Lansing (http://www. mbi.org).

\section{Abbreviations}

AFEX: Ammonia Fiber Expansion; AFEX-CS: AFEX treated corn stover; BESC: BioEnergy Science Center; BSA: bovine serum albumin; CAZymes: carbohydrate-active enzymes; $\mathrm{CBH}$ : cellobiohydrolase; CBM: carbohydrate binding module; CD: catalytic domain; CS: corn stover; DA-CS: dilute acid treated corn stover; EG: endoglucanase; FPLC: fast performance liquid chromatography; GFP: green fluorescent protein;
GLBRC: Great Lakes Bioenergy Research Center; IL-CS: ionic liquid treated corn stover; JBEl: Joint BioEnergy Institute; PASC: phosphoric acid swollen cellulose; PDB: Protein Data Bank; RFU: relative fluorescence units.

\section{Competing interests}

The authors declare that they have no competing interests.

\section{Authors' contributions}

DG, TAW, and SPSC designed the research; DG, CH, and SPSC carried out the experiments; DG, CH, VB, TAW, BED, and SPSC analyzed the data and reviewed the manuscript; DG, CH, TAW, and SPSC wrote the manuscript. All authors have read and approved the final manuscript.

\section{Acknowledgements}

This work was funded by the DOE Great Lakes Bioenergy Research Center (supported by the Department of Energy, Office of Science, Office of Biological and Environmental Research, through Cooperative Agreement DE-FC02-07ER64494 between The Board of Regents of the University of Wisconsin System and the Department of Energy (DG, VB, BED, SPSC) and from the National Science Foundation Grant Number 1236120 (CBET - Energy for Sustainability) (CH, TAW, SPSC). We would like to acknowledge Prof. Charles Wyman's laboratory (University of California, Riverside) for providing DA pretreated corn stover, and colleagues at JBEI (Seema Singh and Blake Simmons) for providing IL pretreated biomass. We thank Dr. Saee Keskar (Michigan State University) for assistance with optimizing the lignin extraction protocol and Prof. Brian Fox (University of Wisconsin - Madison) for providing the pEC plasmid. Special thanks go to the Genencor Division of Danisco (USA), for their generous gift of enzymes. We would like to thank Michigan Biotechnology Institute (MBI) for access to their FPLC system.

\section{Author details}

'Department of Chemical Engineering and Materials Science, Michigan State University, East Lansing, MI 48824, USA. ${ }^{2}$ Great Lakes Bioenergy Research Center (GLBRC), Michigan State University, 164 Food Safety and Toxicology Building, East Lansing, Ml 48824, USA. ${ }^{3}$ Biomass Conversion Research Lab (BCRL), MBI Building, 3900 Collins Road, East Lansing, MI 48910, USA. ${ }^{4}$ Department of Biosystems and Agricultural Engineering, Michigan State University, East Lansing, Ml 48824, USA. ${ }^{5}$ Department of Chemical \& Biochemical Engineering, Rutgers, The State University of New Jersey, 98 Brett Road, Room C-150A, Piscataway, NJ 08854, USA.

Received: 23 September 2014 Accepted: 27 November 2014 Published online: 13 December 2014

\section{References}

1. Ragauskas AJ, Williams CK, Davison BH, Britovsek G, Cairney J, Eckert CA, Frederick WJ, Hallett JP, Leak DJ, Liotta CL, Mielenz JR, Murphy R, Templer R, Tschaplinski T: The path forward for biofuels and biomaterials. Science (80) 2006, 311:484-489.

2. Chundawat SPS, Beckham GT, Himmel M, Dale BE: Deconstruction of lignocellulosic biomass to fuels and chemicals. Annu Rev Chem Biomol Eng 2011, 2:121-145.

3. Himmel ME, Ding SY, Johnson DK, Adney WS, Nimlos MR, Brady JW, Foust TD: Biomass recalcitrance: engineering plants and enzymes for biofuels production. Science (80) 2007, 315:804-807.

4. Horn SJ, Vaaje-Kolstad G, Westereng B, Eijsink VG: Novel enzymes for the degradation of cellulose. Biotechnol Biofuels 2012, 5:45.

5. Somerville C: Cellulose synthesis in higher plants. Annu Rev Cell Dev Biol 2006, 22:53-78.

6. Somerville C, Bauer S, Brininstool G, Facette M, Hamann T, Milne J, Osborne E, Paredez A, Persson S, Raab T, Vorwerk S, Youngs H: Toward a systems approach to understanding plant-cell walls. Science (80) 2004, 306:2206-2211.

7. Lynd LR, Weimer PJ, van ZyI WH, Pretorius IS: Microbial cellulose utilization: fundamentals and biotechnology. Microbiol Mol Biol Rev 2002, 66:506-577.

8. Shoseyov O, Shani Z, Levy I: Carbohydrate binding modules: biochemical properties and novel applications. Microbiol Mol Biol Rev 2006, 70:283-295.

9. Payne CM, Resch MG, Chen L, Crowley MF, Himmel ME, Taylor LE, Sandgren M, Ståhlberg J, Stals I, Tan Z, Beckham GT: Glycosylated linkers in multimodular lignocellulose-degrading enzymes dynamically bind to cellulose. Proc Natl Acad Sci U S A 2013, 110:14646-14651. 
10. Srisodsuk M, Reinikainen $T$, Penttila $M$, Teeri $\Pi$ : Role of the interdomain linker peptide of Trichoderma reesei cellobiohydrolase I in its interaction with crystalline cellulose. J Biol Chem 1993, 268:20756-20761.

11. Igarashi K, Koivula A, Wada M, Kimura S, Penttila M, Samejima M: High speed atomic force microscopy visualizes processive movement of Trichoderma reesei cellobiohydrolase I on crystalline cellulose. J Biol Chem 2009, 284:36186-36190.

12. Ståhlberg J: Trichoderma reesei has no true exo-cellulase: all intact and truncated cellulases produce new reducing end groups on cellulose. Biochim Biophys Acta 1993, 1157:107-113.

13. Herve C, Rogowski A, Blake AW, Marcus SE, Gilbert HJ, Knox JP: Carbohydrate-binding modules promote the enzymatic deconstruction of intact plant cell walls by targeting and proximity effects. Proc Natl Acad Sci 2010, 107:15293-15298.

14. Foreman PK, Brown D, Dankmeyer L, Dean R, Diener S, Dunn-Coleman NS, Goedegebuur F, Houfek TD, England GJ, Kelley AS, Meerman HJ, Mitchell T, Mitchinson C, Olivares HA, Teunissen PJM, Yao J, Ward M: Transcriptional regulation of biomass-degrading enzymes in the filamentous fungus Trichoderma reesei. J Biol Chem 2003, 278:31988-31997.

15. Gao D, Chundawat SPS, Krishnan C, Balan V, Dale BE: Mixture optimization of six core glycosyl hydrolases for maximizing saccharification of ammonia fiber expansion (AFEX) pretreated corn stover. Bioresour Technol 2010, 101:2770-2781.

16. Rosgaard L, Pedersen S, Langston J, Akerhielm D, Cherry J, Meyer A: Evaluation of minimal Trichoderma reesei cellulase mixtures on differently pretreated barley straw substrates. Biotechnol Prog 2007, 23:1270-1276.

17. Gao D, Chundawat SPS, Liu T, Hermanson S, Gowda K, Brumm P, Dale BE, Balan V: Strategy for identification of novel fungal and bacterial glycosyl hydrolase hybrid mixtures that can efficiently saccharify pretreated lignocellulosic biomass. BioEnergy Res 2010, 3:67-81.

18. Banerjee G, Car S, Scott-Craig J, Borrusch M, Walton J: Rapid optimization of enzyme mixtures for deconstruction of diverse pretreatment/biomass feedstock combinations. Biotechnol Biofuels 2010, 3:22

19. Chundawat SPS, Lipton MS, Purvine SO, Uppugundla N, Gao D, Balan V, Dale BE: Proteomics based compositional analysis of complex cellulasehemicellulase mixtures. J Proteome Res 2011, 10:4365-4372.

20. Jørgensen $\mathrm{H}$, Kristensen JB, Felby C: Enzymatic conversion of lignocellulose into fermentable sugars: challenges and opportunities. Biofuels, Bioprod Biorefining 2007, 1:119-134.

21. Chundawat SPS, Bellesia G, Uppugundla N, Sousa L, Gao D, Cheh A, Agarwal U, Bianchetti C, Phillips G, Langan P, Balan V, Gnanakaran S, Dale BE: Restructuring the crystalline cellulose hydrogen bond network enhances its depolymerization rate. J Am Chem Soc 2011, 133:11163-11174.

22. Jeoh T, Ishizawa Cl, Davis MF, Himmel ME, Adney WS, Johnson DK Cellulase digestibility of pretreated biomass is limited by cellulose accessibility. Biotechnol Bioeng 2007, 98:112-122.

23. Chundawat SPS, Donohoe BS, Sousa L, Elder T, Agarwal UP, Lu F, Ralph J, Himmel ME, Balan V, Dale BE: Multi-scale visualization and characterization of plant cell wall deconstruction during thermochemical pretreatment. Energy Environ Sci 2011, 4:973-984.

24. Palonen H, Tjerneld F, Zacchi G, Tenkanen M: Adsorption of Trichoderma reesei $\mathrm{CBH}$ I and EG II and their catalytic domains on steam pretreated softwood and isolated lignin. J Biotechnol 2004, 107:65-72.

25. Sammond DW, Yarbrough JM, Mansfield E, Bomble YJ, Hobdey SE, Decker SR, Taylor LE, Resch MG, Bozell JJ, Himmel ME, Vinzant TB, Crowley MF: Predicting enzyme adsorption to lignin films by calculating enzyme surface hydrophobicity. J Biol Chem 2014, 289:20960-20969.

26. Lou H, Zhu JY, Lan TQ, Lai H, Qiu X: pH-Induced lignin surface modification to reduce nonspecific cellulase binding and enhance enzymatic saccharification of lignocelluloses. Chem Sus Chem 2013, 6:919-927.

27. Martin-Sampedro R, Rahikainen JL, Johansson L-S, Marjamaa K, Laine J, Kruus K, Rojas OJ: Preferential adsorption and activity of monocomponent cellulases on lignocellulose thin films with varying lignin content. Biomacromolecules 2013, 14:1231-1239.

28. Kumar L, Arantes V, Chandra R, Saddler J: The lignin present in steam pretreated softwood binds enzymes and limits cellulose accessibility. Bioresour Technol 2012, 103:201-208.

29. Rahikainen J, Mikander S, Marjamaa K, Tamminen T, Lappas A, Viikari L, Kruus K: Inhibition of enzymatic hydrolysis by residual lignins from softwood - study of enzyme binding and inactivation on lignin-rich surface. Biotech Bioeng 2011, 108:2823-2834.

30. Berlin A, Gilkes N, Kurabi A, Bura R, Tu M, Kilburn D, Saddler J: Weak lignin-binding enzymes. Appl Biochem Biotechnol 2005, 121:163-170.

31. Kumar R, Wyman CE: An improved method to directly estimate cellulase adsorption on biomass solids. Enzyme Microb Technol 2008, 42:426-433.

32. Kumar R, Wyman CE: Cellulase adsorption and relationship to features of corn stover solids produced by leading pretreatments. Biotechnol Bioeng 2009, 103:252-267

33. Várnai A, Viikari L, Marjamaa K, Siika-aho M: Adsorption of monocomponent enzymes in enzyme mixture analyzed quantitatively during hydrolysis of lignocellulose substrates. Bioresour Technol 2011, 102:1220-1227.

34. Chundawat SPS, Vismeh R, Sharma L, Humpula J, Sousa L, Chambliss CK, Jones AD, Balan $\mathrm{V}$, Dale BE: Multifaceted characterization of cell wall decomposition products formed during ammonia fiber expansion (AFEX) and dilute-acid based pretreatments. Biores Technol 2010, 101:8429-8438.

35. Humpula JF, Uppugundla N, Vismeh R, Sousa L, Chundawat SPS, Jones AD, Balan V, Dale BE, Cheh AM: Probing the nature of AFEX-pretreated corn stover derived decomposition products that inhibit cellulase activity. Bioresour Technol 2014, 152:38-45

36. Ximenes E, Kim Y, Mosier N, Dien B, Ladisch M: Inhibition of cellulases by phenols. Enzyme Microb Technol 2010, 46:170-176.

37. Chen F, Dixon RA: Lignin modification improves fermentable sugar yields for biofuel production. Nat Biotechnol 2007, 25:759-761.

38. Wilkerson CG, Mansfield SD, Lu F, Withers S, Park J-Y, Karlen SD, GonzalesVigil E, Padmakshan D, Unda F, Rencoret J, Ralph J: Monolignol ferulate transferase introduces chemically labile linkages into the lignin backbone. Science (80-) 2014, 344:90-93.

39. Studer MH, DeMartini JD, Davis MF, Sykes RW, Davison B, Keller M, Tuskan GA, Wyman CE: Lignin content in natural Populus variants affects sugar release. Proc Natl Acad Sci 2011, 108:6300-6305.

40. Várnai $A$, Siika-aho M, Viikari L: Restriction of the enzymatic hydrolysis of steam-pretreated spruce by lignin and hemicellulose. Enzyme Microb Technol 2010, 46:185-193.

41. Xu F, Ding H, Osborn D, Teijirian A, Brown K, Albano W, Sheehy N, Langston $\mathrm{J}$ : Partition of enzymes between the solvent and insoluble substrate during the hydrolysis of lignocellulose by cellulases. J Mol Catal B Enzym 2008, 51:42-48.

42. Yang B, Wyman CE: BSA treatment to enhance enzymatic hydrolysis of cellulose in lignin containing substrates. Biotechnol Bioeng 2006, 94:611-617.

43. Kristensen JB, Borjesson J, Bruun MH, Tjerneld F, Jorgensen $\mathrm{H}$ : Use of surface active additives in enzymatic hydrolysis of wheat straw lignocellulose. Enzyme Microb Technol 2007, 40:888-895.

44. Tu M, Chandra RP, Saddler JN: Recycling cellulases during the hydrolysis of steam exploded and ethanol pretreated lodgepole pine. Biotechnol Prog 2007, 23:1130-1137.

45. Gao D, Chundawat SPS, Uppugundla N, Balan V, Dale BE: Binding characteristics of Trichoderma reesei cellulases on untreated, ammonia fiber expansion and dilute-acid pretreated lignocellulosic biomass. Biotech Bioeng 2011, 108:1788-1800.

46. Gao D, Chundawat SPS, Sethi A, Balan V, Gnanakaran S, Dale BE: Increased enzyme binding to substrate is not necessary for more efficient cellulose hydrolysis. Proc Natl Acad Sci 2013, 110:10922-10927.

47. Gao D, Uppugundla N, Chundawat S, Yu X, Hermanson S, Gowda K, Brumm P, Mead D, Balan V, Dale B: Hemicellulases and auxiliary enzymes for improved conversion of lignocellulosic biomass to monosaccharides. Biotechnol Biofuels 2011, 4:5

48. Singh S, Simmons BA, Vogel KP: Visualization of biomass solubilization and cellulose regeneration during ionic liquid pretreatment of switchgrass. Biotechnol Bioeng 2009, 104:68-75.

49. Cetinkol OP, Dibble DC, Cheng G, Kent MS, Knierim B, Auer M, Wemmer DE, Pelton JG, Melnichenko YB, Ralph J, Simmons BA, Holmes BM: Understanding the impact of ionic liquid pretreatment on eucalyptus. Biofuels 2010, 1:33-46.

50. $\mathrm{Pu} \mathrm{Y,} \mathrm{Hu} \mathrm{F,} \mathrm{Huang} \mathrm{F,} \mathrm{Davison} \mathrm{BH,} \mathrm{Ragauskas} \mathrm{AJ:} \mathrm{Assessing} \mathrm{the} \mathrm{molecular}$ structure basis for biomass recalcitrance during dilute acid and hydrothermal pretreatments. Biotechnol Biofuels 2013, 6:15.

51. Pan XJ: Role of functional groups in lignin inhibition of enzymatic hydrolysis of cellulose to glucose. J Biobased Mater Bioenergy 2008, 2:25-32.

52. Shallom D, Shoham Y: Microbial hemicellulases. Curr Opin Microbiol 2003, 6:219-228. 
53. Appeldoorn MM, Kabel MA, Van Eylen D, Gruppen H, Schols HA: Characterization of oligomeric xylan structures from corn fiber resistant to pretreatment and simultaneous saccharification and fermentation. J Agric Food Chem 2010, 58:11294-11301.

54. Lantz SE, Goedegebuur F, Hommes R, Kaper T, Kelemen BR, Mitchinson C, Wallace L, Stahlberg J, Larenas EA: Hypocrea jecorina Cel6A protein engineering. Biotechnol Biofuels 2010, 3:20.

55. Reese ET, Mandels M: Stability of the cellulase of Trichoderma reesei under use conditions. Biotech Bioeng 1980, 22:323-335.

56. Jiménez J, Domínguez JM, Castillón MP, Acebal C: Thermoinactivation of cellobiohydrolase I from Trichoderma reesei QM 9414. Carbohydr Res 1995, 268:257-266.

57. Zoungrana T, Findenegg GH, Norde W: Structure, stability, and activity of adsorbed enzymes. J Colloid Interface Sci 1997, 190:437-448.

58. Gör P, Linder M, Reinikainen T, Drakenberg T, Mattinen M-L, Annila A, Kontteli M, Lindeberg G, Ståhlberg J: Identification of functionally important amino acids in the cellulose-binding domain of Trichoderma reesei cellobiohydrolase I. Protein Sci 1995, 4:1056-1064.

59. Beckham GT, Matthews JF, Bomble YJ, Bu L, Adney WS, Himmel ME, Nimlos MR, Crowley MF: Identification of amino acids responsible for processivity in a Family 1 carbohydrate-binding module from a fungal cellulase. J Phys Chem B 2010, 114:1447-1453.

60. Rahikainen JL, Evans JD, Mikander S, Kalliola A, Puranen T, Tamminen T, Marjamaa K, Kruus K: Cellulase-lignin interactions - the role of carbohydrate-binding module and $\mathrm{pH}$ in non-productive binding. Enzyme Microb Technol 2013, 53:315-321.

61. Nakagame S, Chandra RP, Kadla JF, Saddler JN: Enhancing the enzymatic hydrolysis of lignocellulosic biomass by increasing the carboxylic acid content of the associated lignin. Biotech Bioeng 2011, 108:538-548.

62. Zhang YHP, Cui JB, Lynd LR, Kuang LR: A transition from cellulose swelling to cellulose dissolution by o-phosphoric acid: evidence from enzymatic hydrolysis and supramolecular structure. Biomacromolecules 2006, 7:644-648.

63. Balan V, Bals B, Chundawat SP, Marshall D, Dale BE: Lignocellulosic biomass pretreatment using AFEX. Biofuels Methods Protoc 2009, 581:61-77.

64. Chundawat SPS, Balan V, Dale BE: High-throughput microplate technique for enzymatic hydrolysis of lignocellulosic biomass. Biotechnol Bioeng 2008, 99:1281-1294.

65. Lau M, Gunawan C, Dale B: The impacts of pretreatment on the fermentability of pretreated lignocellulosic biomass: a comparative evaluation between ammonia fiber expansion and dilute acid pretreatment. Biotechnol Biofuels 2009, 2:30

66. Lloyd TA, Wyman CE: Combined sugar yields for dilute sulfuric acid pretreatment of corn stover followed by enzymatic hydrolysis of the remaining solids. Bioresour Technol 2005, 96:1967-1977.

67. Li C, Cheng G, Balan V, Kent MS, Ong M, Chundawat SPS, daCosta Sousa L, Melnichenko YB, Dale BE, Simmons BA, Singh S: Influence of physicochemical changes on enzymatic digestibility of ionic liquid and AFEX pretreated corn stover. Bioresour Technol 2011, 102:6928-6936.

68. Bjorkman A: Isolation of lignin from finely divided wood with neutral solvents. Nature (London) 1954, 174:1057-1058.

69. Lim S, Chundawat SPS, Fox BG: Expression, purification and characterization of a functional carbohydrate-binding module from Streptomyces sp. SirexAA-E. Protein Expr Purif 2014, 98:1-9.

70. Studier FW: Protein production by auto-induction in high-density shaking cultures. Protein Expr Purif 2005, 41:207-234.

71. Hong J, Wang $Y$, Ye $X$, Zhang YHP: Simple protein purification through affinity adsorption on regenerated amorphous cellulose followed by intein self-cleavage. J Chromatogr A 2008, 1194:150-154

72. Tomme P, Boraston A, McLean B, Kormos J, Creagh AL, Sturch K, Gilkes NR, Haynes CA, Warren RAJ, Kilburn DG: Characterization and affinity applications of cellulose-binding domains. J Chromatogr B Biomed Sci Appl 1998, 715:283-296.
73. Ward WW, Prentice HJ, Roth AF, Cody CW, Reeves SC: Spectral perturbations of the Aequorea green-fluorescent protein. Photochem Photobiol 1982, 35:803-808.

74. Jacak R, Leaver-Fay A, Kuhlman B: Computational protein design with explicit consideration of surface hydrophobic patches. Proteins 2012 80:825-838

75. DeLano WL: The PyMOL Molecular Graphics System. San Carlos, CA, USA: DeLano Scientific LLC; 2002. http://www.pymol.org.

doi:10.1186/s13068-014-0175-x

Cite this article as: Gao et al:: Lignin triggers irreversible cellulase loss during pretreated lignocellulosic biomass saccharification. Biotechnology for Biofuels 2014 7:175.

\section{Submit your next manuscript to BioMed Central and take full advantage of:}

- Convenient online submission

- Thorough peer review

- No space constraints or color figure charges

- Immediate publication on acceptance

- Inclusion in PubMed, CAS, Scopus and Google Scholar

- Research which is freely available for redistribution

Submit your manuscript at www.biomedcentral.com/submit
C Biomed Central 